\title{
Optimal management of health care for persons with disability related to spinal cord injury: learning from the Sunnaas model of telerehabilitation
}

\author{
Ingebjørg Irgens ${ }^{1,2} \cdot$ Bodil Bach $^{3} \cdot$ Tiina Rekand $\mathbb{C}^{4,5} \cdot$ Sveinung Tornås ${ }^{1}$
}

Received: 19 July 2020 / Revised: 21 August 2020 / Accepted: 25 August 2020

(c) The Author(s) 2020. This article is published with open access

Telemedicine [1] has changed the way of offering medical services around the world. It has rapidly been brought to the forefront because of the Covid-19 pandemic [2]. We believe this should be a permanent change and that telemedicine should be included as part of every hospital system of care. Individuals with disabilities, like spinal cord injury (SCI), or persons living far away from specialized care centers often have problems with traveling long distances [3, 4]. Varying weather conditions due to climate change, as well as pandemics with the need to reduce the risk of infection [5] have induced the necessity for health care providers think creatively about seeing patients, rather than patients only have the option to travel to hospitals and outpatient clinics. Telemedicine is a way to overcome these limitations [1-3].

Almost 100 years ago, teleradiology as communication support for the health care providers, was in use on the Queen Mary [6], but it is just recently that telemedicine for medical purposes has expanded all over the world [7]. Today, many options are available for patients in need of long-term follow-up [8]. The purpose of this perspective is to explain how we managed to implement telerehabilitation

Ingebjørg Irgens

Ingebjorg.irgens@sunnaas.no

1 Sunnaas Rehabilitation Hospital, Bjørnemyrveien 11, 1450 Nesoddtangen, Norway

2 Institute of Clinical Medicine, University of Oslo, PO Box 1171, Blindern, 0318 Oslo, Norway

3 SMARTsam AS, Bølgenveien 8, 3514 Hønefoss, Norway

4 Department of Neurology/Spinal Cord Unit, Haukeland University Hospital, Jonas Lies vei 65, 5053 Bergen, Norway

5 Sahlgrenska Academy and Institute for Neuroscience and Physiology, University of Gothenburg, Box 100, S-405 30 Gothenburg, Sweden as part of our system of care, in hopes that others will follow suit.

Sunnaas rehabilitation hospital provides services for individuals in need of highly specialized rehabilitation due to severe impairments, like SCI, multi trauma, burn injury, neurodegenerative conditions, stroke, traumatic brain injury, cerebral palsy, and poliomyelitis. The Spinal Cord Unit at the hospital offers life-long follow-up rehabilitation for individuals with SCI and associated conditions. An important task is to ensure the best possible services to our patients and their families $[9,10]$, which requires cooperation from a vast number of disciplines (see Fig. 1).

Due to our large catchment area and the geography of Norway, long-term and life-long follow-up are challenging. As a result, we have fostered a successful model of telerehabilitation via videoconference in our health care organization [11-15], the Sunnaas model of telerehabilitation. We believe this model improves public health, and supports more sustainable health services, including accessibility, prevention, earlier treatment and better interaction and knowledge transfer between health care providers on different levels (Fig. 1). Moreover, it is particularly important to ensure good coordination when the responsibility for the patient is transferred between hospitals and municipalities, and between departments and units within hospitals and municipalities [16]. The benefit of including patients, relatives, as well as health care collaborators in treatment team meetings and group decisions is obvious, in particular when this collaborating also protects the environment as there is significantly less driving involved.

This perspective gives a suggestion of how to implement telerehabilitation in the health care service of a hospital.

We define telerehabilitation as communication by videoconferencing via PC, laptop, tablets, or mobile phone to improve the wellness or rehabilitation status of an individual. We have used both integrated and external webcams. Encrypted communication takes place in real time 


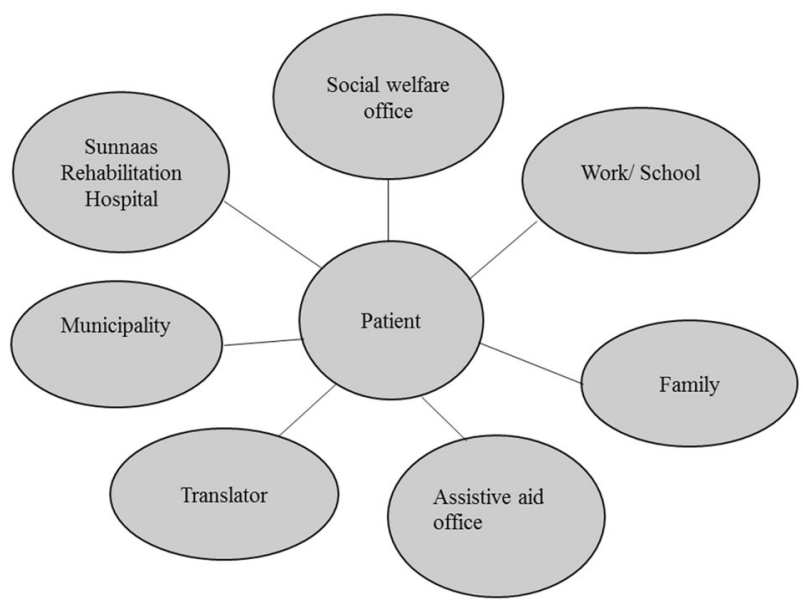

Fig. 1 The different participants in the rehabilitation process. To ensure the best possible services to the care receivers during the rehabilitation process, coordination and collaboration from a vast number of collaborators are required.

without recording or archiving and must be in accordance with legislation regarding data safety, privacy, and confidentiality applicable in the country/region.

Notes, pictures, and evaluations are documented in the electronic medical record.

Only necessary members of the multidisciplinary team and external care providers participate in the videoconference, and participants must receive training in ethical guidelines and in the use of the equipment before participating as a telerehabilitation provider.

Moreover, despite the fact that we implemented telerehabilitation services 7 years ago into our outpatient system of care for people with SCI [12], we recently expanded this service into other diagnostic groups, such as stroke and cerebral palsy $[13,14]$. We have also incorporated exercise supervision via telerehabilitation [17].

Our organizational model is presented in Table 1 (see Table 1). The model includes education and mentoring to staff members, colleagues at collaborative hospitals, local home care providers, patients and their family members. People in need of continuous follow-up, such as individuals with SCI and other severe disabilities, benefit from our approach, which includes local providers, because rehabilitation is an ongoing process and a large part of it takes place after discharge, in the local environment. Thus providing services at home is conducive to optimizing the lifestyle of the person with the disability [8].

Our inpatient-based service has been especially useful during the Covid-19 pandemic in order to allow people to participate in rehabilitation even if they are in isolation. The model also makes it possible to collaborate with the local care providers while the individual is still an inpatient and thus effectively plan discharge to their municipality. This is particularly important for individuals with life-long follow-up
Table 1 The Sunnaas model of telerehabilitation.

Health service Intention
delivery

Collaborative meeting with the municipality

Multidisciplinary meetings

- Before discharge

- Before admission

- After hospitalization

Courses and knowledge exchange

Knowledge translation, meetings, and courses

Assistive aid dissemination

Interpreter services

Isolation rooms due to infectious disease

Consultations with specialists in other hospitals

Outpatient follow-up consultations

Courses, competence exchange, and discussions related to specific topics via videoconference, web or e-learning courses.

- More participants and more discussion =increased knowledge translation

- Learning and coping courses

Dialogue with the assistive aid office Increased consumer participation

Interpreter assisting via videoconferencing

- Regional interpreting center is established

- Qualified health interpreters

- Aim; $40 \%$ videoconference interpretation

- Great potential also in the municipality

- Patient education

- Education about infection routines

- Municipal meetings

- Interpreter assistance

- Dialogue with the nurse-staff room when needed

- Fill out forms with help from members of the multidisciplinary team

Patient consultations with specialists in other hospitals

Example:

- Pressure injury, burn injury, fractures, and spinal cord injury

- External camera is connected to the screen to secure detailed visual information

Consultation with the outpatient clinic

- Videoconference to the patient in his and her home

- Local health care providers attending

- GP attending

- Attendance from external medical specialists

Exercise

Physiotherapists performing adjusted exercise via videoconference

Services delivered via videoconference by the multidisciplinary team.

needs, like SCI. Finally, performing videoconference meetings before admittance to the rehabilitation hospital makes it possible to personalize and customize the hospitalization stay.

Rehabilitation services should be available for all individuals with impaired function due to injury or sickness. Thus, health care should be organized and planned to include the provision of rehabilitation services, no matter the geographical location of the caregiver or care receiver. Videoconferencing is a good tool for cooperation in the 
Fig. 2 Success criteria in the implementation and usage of new, technological services. The organization must pay attention to user involvement, potential barriers, complexities and context regarding the new solutions.

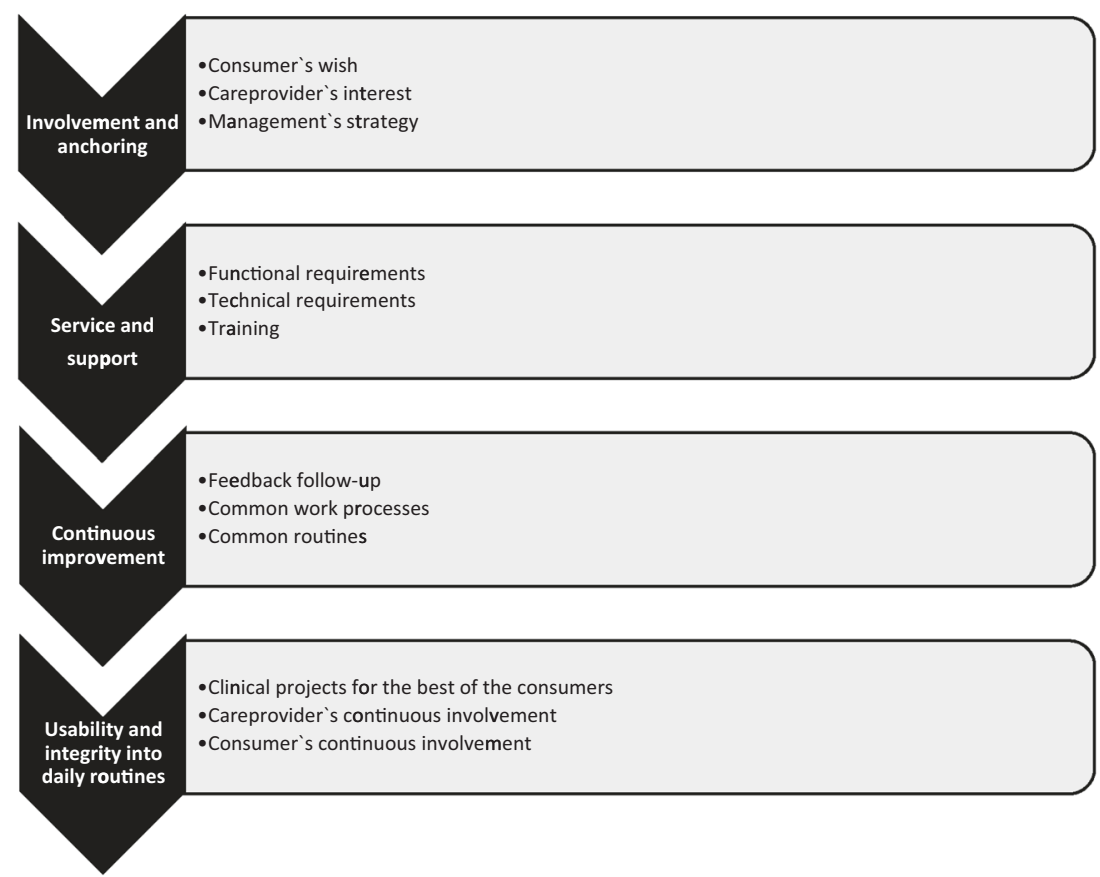

rehabilitation process $[1,3,8]$ and we have found our model is beneficial for all persons who are discharged to home from inpatient rehabilitation. Optimizing the cooperation with local authorities, consumer organizations, and other relevant partners ensures sufficient and adequate capacity, reasonable structure, appropriate expertise and activities in a way that secures quality care and patient safety $[9,10]$. The model contributes to effective, safe, and predictable interactions that allow specialized rehabilitation providers to share and transfer their competence to providers at a local level while also including consumers as active participants in the process $[11,12]$. It allows the health care system to coordinate follow-up at a local level [18-20] and we believe now more than ever it is important to offer proper treatment at the right place at the right time [16].

Geographical locations can be a barrier to receive the needed rehabilitation service, because long-distance traveling can cause suffering for patients, e.g., patients with SCI and pressure injuries [21]. Expenses associated with transportation are large in terms of time and money, but the expenses are large also in terms of the carbon footprint [21]. Videoconferencing ensures consumers receive necessary follow-up, and makes it possible for caregivers and local health care providers to interact virtually [20, 22]. The end result is proximity at a distance between all participants [11, 19]. Active feedback from consumers, their relatives and the municipal health care service have revealed our telerehabilitation services are more adapted to everyday life [11] for individuals with complex needs in need of longterm follow-up, such as people with SCI [8, 11-15, 18-21].
Having full support of organizational management, technical assistance, and development of dynamic guidelines are important factors for success. Complex management structures, lack of infrastructure, poor communications technology, and founding are barriers to implementation.

The Covid-19 pandemic has resulted in a massive increase in telemedicine services in conjunction with improved funding in some countries. Fortunately, new software-based videoconferencing services, which have recently been available around the world, have decreased the need for start-up costs. However, coordination of care remains problematic and potential solutions need to be addressed. We believe it is important that stakeholders are involved in service development and evaluation and we have done this in the Sunnas model [22].

Historically, we performed a feasibility study, which lead to implementation of this service in the outpatient clinic [12]. Furthermore, we developed a telemedicine team (TMT) with specialized expertise and dedicated time to be included in all new clinical projects and feasibility studies. Guidelines were developed and were continuously updated and available on the organization's web page. Figure 2 shows criteria to be taken into account in the implementation of new services (see Fig. 2). Training for all participants of the service remains important as are instructions and check lists (see Fig. 3) with a focus on ethical issues, professional quality, and safety for the participants.

Establishment of an equipment replacement and software update plan and a videoconference-network for sharing 


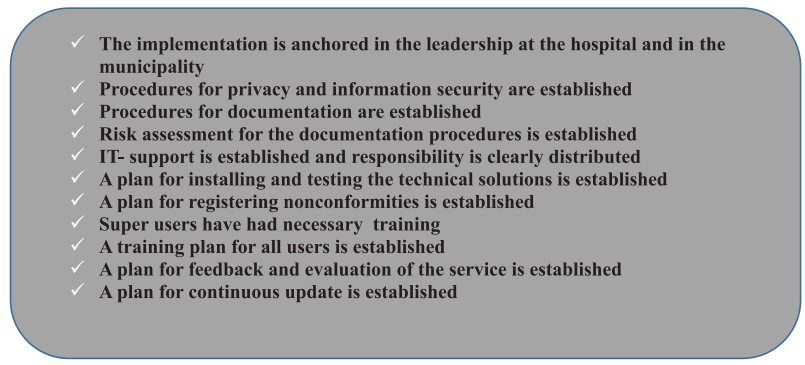

Fig. 3 A checklist for development and use of new, technological services. The checklist should focus on ethical issues, availability, professional quality, safety and training for all participants of the service.

experiences and ideas with organizations outside the hospital is important. The success of establishing a telerehabilitation system of care $20 \%$ dependent on technology and $80 \%$ on organizational support $[12,19,23,24]$.

Our model has been a success in the outpatient followup of persons with SCI, facilitating testing and implementation of new, technological health care solutions, and we recommend replication to other patient groups and diagnoses, because the benefits of telerehabilitation are undeniable.

\section{Compliance with ethical standards}

Conflict of interest The authors declare that they have no conflict of interest.

Publisher's note Springer Nature remains neutral with regard to jurisdictional claims in published maps and institutional affiliations.

Open Access This article is licensed under a Creative Commons Attribution 4.0 International License, which permits use, sharing, adaptation, distribution and reproduction in any medium or format, as long as you give appropriate credit to the original author(s) and the source, provide a link to the Creative Commons license, and indicate if changes were made. The images or other third party material in this article are included in the article's Creative Commons license, unless indicated otherwise in a credit line to the material. If material is not included in the article's Creative Commons license and your intended use is not permitted by statutory regulation or exceeds the permitted use, you will need to obtain permission directly from the copyright holder. To view a copy of this license, visit http://creativecommons. org/licenses/by/4.0/.

\section{References}

1. Demiris G. Integration of telemedicine in graduate medical informatics education. J Am Med Inform Assoc. 2003;10:310-4. https://doi.org/10.1197/jamia.M1280.

2. Centers for Disease Control and Prevention. Using telehealth to expand access to essential health services during the COVID-19 pandemic. National Center for Immunization and Respiratory
Diseases (NCIRD), division of viral diseases. 2020. https://www. cdc.gov/coronavirus/2019-ncov/hcp/telehealth.html. Downloaded June 5th 2017.

3. Banbury A, Nancarrow S, Dart J, Gray L, Parkinson L. Telehealth interventions delivering home-based support group videoconferencing: systematic review. J Med Internet Res. 2018;20:e25. https://doi.org/10.2196/jmir.8090.

4. Tyagi N, Goel SA, Alexander M. Improving quality of life after spinal cord injury in India with telehealth. Spinal Cord Ser Cases. 2019;5:70. https://doi.org/10.1038/s41394-019-0212-x.

5. Siwicki B. Telemedicine during COVID-19: benefits, limitations, burdens, adaptation. Healthcare IT news. 2020. https://www.hea 1thcareitnews.com/news/telemedicine-during-covid-19-benefitslimitations-burdens-adaptation. Downloaded April 28th 2020.

6. Thrall JH. Teleradiology: part I. History and clinical applications. Radiology. 2007;243-3:613-7. https://doi.org/10.1148/radiol. 2433070350.

7. Bruggeman L. Telemedicine is having a moment. How can patients make use of the growing industry? abc news. 2020. https://abcnews.go.com/Health/telemedicine-moment-patients-ma ke-growing-industry/story?id $=69738388$. Downloaded April 28th 2020.

8. Irgens I, Rekand T, Arora M, Liu N, Marshall R, BieringSørensen F, et al. Telehealth for people with spinal cord injury: a narrative review. Spinal Cord. 2018;56:643-55. https://doi.org/10. 1038/s41393-017-0033-3.

9. Sunnaas sykehus HF. (Strategy plan 2019-2035). https://www. sunnaas.no/Documents/M\%C3\%A51\%20og\%20strategier/Sunnaa s\%20sykehus\%20HF\%20strategisk\%20plan\%202035.pdf.

10. Meld. St. 11 (2015-2016)—Nasjonal helse—og sykehusplan. (National plan for health and hospitals). 2020. https://www. regjeringen.no/contentassets/7b6ad7e0ef1a403d97958bcb344 78609/no/pdfs/stm201520160011000dddpdfs.pdf. Downloaded April 28th 2020

11. Aune G, Aanestad M. Oppfølging fra spesialisthelsetjenesten hjemme hos pasienten (Follow-up from the specialized health care service in the patient's home). In: Moser I (ed). Velferdsteknologi. En ressursbok. (Welfare technology. A resource manual). 1st edn. Oslo: Cappelen Damm Akademisk; 2019, pp 69-84.

12. Irgens I, Kleven L, Sørli H, Stanghelle JK, Rekand T. Telemedicine brings specialist healthcare services to patients' homes. Tidsskr Nor Legeforen. 2015;135:1716-7. https://doi.org/10. 4045/tidsskr.15.0770. Nr. 19-20.

13. Øra HP, Kirmess M, Brady MC, Sørli H, Becker F. Technical features, feasibility, and acceptability of augmented telerehabilitation in poststroke aphasia-experiences from a randomized controlled trial. Front Neurol. 2020. https://doi.org/10. 3389/fneur.2020.00671.

14. Øra HP, Kirmess M, Brady MC, Becker F. The effect of augmented speech-language therapy delivered by telerehabilitation on poststroke aphasia- a pilot randomized controlled trial. Clin Rehabil. 2020. https://doi.org/10.1177/0269215519896616.

15. Høye H, Jahnsen RB, Løvstad M, Hartveit JF, Sørli H, Tornås S, et al. A mindfulness-based stress reduction program via group video conferencing for adults with cerebral palsy - a pilot study. Front Neurol. 2020. https://doi.org/10.3389/fneur.2020.00195.

16. Report No. 47 to the Storting (2008-2009). The coordination reform - proper treatment-at the right place and right time. 2020. https://www.regjeringen.no/en/dokumenter/report.no.-47-to-thestorting-2008-2009/id567201/. Downloaded April 29th 2020.

17. Kvistum I. Nytt treningstilbud får helseministeren til å svette. Handikapnytt.no 2018. Sept. 16; (New training facilities makes the Minister of Health sweat). 2020. https://www.handikapnytt.no/ nytt-treningstilbud-far-helseministeren-til-a-svette/. Downloaded August 3rd 2020. 
18. Finch T, May C, Mair F, Mort M, Gask L. Integrating service development with evaluation in telehealthcare: an ethnographic study. BMJ. 2003;327:1205-9. https://doi.org/10.1136/bmj.327. 7425.1205 .

19. Aanestad M, Driveklepp AM, Sørli H, Hertzum M. Participatory continuing design: "Living with" videoconferencing in rehabilitation. In: Kanstrup AM, Blygholm A, Bertelsen P, Nøhr C (eds). Participatory design \& health information technology. 1st edn. Amsterdam: IOS Press BV; 2017. pp 45-59. https://doi.org/10. 3233/978-1-61499-740-5-45.

20. O'Cathail M, Sivanandan MA, Diver C, Patel P, Christian J. The use of patient-facing teleconsultations in the national health service: scoping review. JMIR Med Inform. 2020;8:e15380. https:// doi.org/10.2196/15380.
21. Irgens I, Hoff JM, Sørli H, Haugland H, Stanghelle JK, Rekand T. Hospital based care at home; study protocol for a mixed epidemiological and randomized controlled trial. Trials. 2019;20:1-12. https://doi.org/10.1186/s13063-019-3185-y.

22. Aanestad M, Jensen TB. Collective mindfulness in postimplementation IS adaptation processes. Inf Organ. 2016;26: 3-27. https://doi.org/10.1016/j.infoandorg.2016.02.001.

23. van Dyk L. A review of telehealth service implementation frameworks. Int J Environ Res Public Health. 2014;11:1279-98. https://doi.org/10.3390/ijerph110201279.

24. Moser I. Final report Distributed Home Care Solutions: Possibilities and Limitations (completed). [Report, Project number 204331]. Oslo: Norsk Forskningsråd (Research Council of Norway); 2015. https://www.mn.uio.no/ifi/english/research/projects/reach/. 